\title{
Impact of rock type on the pore structures and physical properties within a tight sandstone reservoir in the Ordos Basin, NW China
}

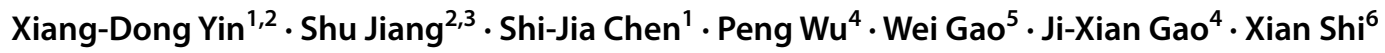

Received: 21 January 2019 / Published online: 21 May 2020

(c) The Author(s) 2020

\begin{abstract}
The pore-throat systems and physical properties of tight sandstone reservoirs are complex, and deposition is thought to be a fundamental control for them. In this study, the impacts of the full ranges of rock types (from pebbly coarse sandstone to fine sandstone) on the pore structures and physical properties of the Permian tight sandstone reservoir in the eastern Ordos Basin were investigated comprehensively through a series of experiments including conventional physical testing, thin-section analysis, scanning electron microscopy, nuclear magnetic resonance analysis and high-pressure mercury injection tests. The results showed that the coarser-grained sandstones tend to have higher feldspar content and lower percentage of cements, leading to strong dissolution, weak cementation and improved porosity and permeability. The medium sandstone has the highest level of quartz and the lowest average content of feldspar, resulting in strong heterogeneity of physical properties. Only those medium sandstone reservoirs with relatively high content of feldspars have better physical properties. Additionally, the coarser-grained sandstones contain relatively large dissolution pores (nearly $200 \mu \mathrm{m}$ ), whereas the finer-grained sandstones have more intercrystalline pores with a relatively more homogeneous pore structure. The pebbly coarse sandstone and coarse sandstone reservoirs are favorable targets with best physical properties.
\end{abstract}

Keywords Pore size distribution · Pore types $\cdot$ Physical properties $\cdot$ Tight sandstone $\cdot$ Ordos Basin

\section{Introduction}

Edited by Jie Hao

Shu Jiang

jiangsu@cug.edu.cn

Shi-Jia Chen

chensj1964@sina.com

1 State Key Laboratory of Oil and Gas Reservoir Geology and Exploration, Southwest Petroleum University, Chengdu 610500, Sichuan, China

2 Key Laboratory of Tectonics and Petroleum Resources of Ministry of Education and School of Earth Resources, China University of Geosciences, Wuhan 430074, Hubei, China

3 Energy and Geoscience Institute, University of Utah, Salt Lake City, UT 84108, USA

4 Unconventional Oil and Gas Branch, CNOOC Ltd., Beijing 100011, China

5 Oil and Gas Technology Research Institute, Changqing Qilfield Company, Xi' an City 710021, Shaanxi, China

6 School of Petroleum Engineering, China University of Petroleum (Huadong), Qingdao 266000, Shandong, China
Compared to shale gas, tight sandstone gas is more practical and significant as an unconventional resource because tight sandstone can be hydraulically fractured more easily than shale (Song et al. 2013). The proven reserve of tight sandstone gas in China is approximately $3.5 \times 10^{12} \mathrm{~m}^{3}$ with an annual production of $169 \times 10^{8} \mathrm{~m}^{3}$, demonstrating a great exploration potential (Zou et al. 2013). Hydraulic fracturing is an important technique for tight sandstone reservoirs (Guo et al. 2015; Feng et al. 2016; Zhao et al. 2016; Wang et al. 2017a, b, c; Tian et al. 2018). Nevertheless, in most basins of the world, reservoir "sweet spots" exist and searching for these "sweet spots" before hydraulic fracturing is crucial for successful exploration and development of tight sandstone gas (Zou et al. 2014; Sun et al. 2015, 2019; Wang et al. 2015; Tian et al. 2016; Zhang et al. 2016; Tang et al. 2017; Zhao et al. 2017). A "sweet spot" is defined as that has better physical properties, such as porosity and permeability. Essentially, pores and throats are controlling factors for reservoir physical properties ( $\mathrm{Li}$ et al. 2017a, b; Huang et al. 2018). Multiple conventional and new methods have 
been applied to characterize the types, sizes and connectivity of pores, as well as the geometry and sizes of throats within tight sandstones. These methods include geochemistry (Sonnenberg and Pramudito 2009; Bjørlykke and Jahren 2012; Clarkson et al. 2012a, b), thin-section analysis (Lame et al. 2004), scanning electron microscopy (Anovitz and Cole 2015; Xi et al. 2016; Zhou et al. 2016; Chen et al. 2017), high-pressure mercury intrusion (Xiao et al. 2011; Clarkson et al. 2012a, b; Shanley and Cluff 2015; Shao et al. 2017), nuclear magnetic resonance (Lai et al. 2016, 2018a; Li et al. 2017a, b; Xiao et al. 2018a, b; Xiao et al. 2018; Zhu et al. 2018;), nitrogen adsorption (Schmitt et al. 2015; Liu et al. 2017) and small angle neutron scattering (Anovitz et al. 2013; Anovitz et al. 2015).

The pore-throat systems and physical properties of tight sandstone reservoirs are complex, and deposition was thought to be a fundamental control for them. Diagenesis exerts more important controls on the pore-throat systems and physical properties. There is ample evidence that diagenesis controls pore structures, as well as the porosity and permeability of tight sandstones (Anovitz et al. 2013, 2015; Lai et al. 2015; Xi et al. 2015; Wang et al. 2017a, b, c; Patrick et al. 2017; Wang et al. 2017a, b, c; Yu et al. 2019). In addition, deposition plays a fundamental and innate role in porosity evolution (Yu et al. 2015). The rock types, mineral composition and the size and arrangement of grains further influence the diagenetic processes and the formation of natural fractures. For example, Wang et al. (2017a, b, c) found that coarse sandstone was prone to have a relatively weak compaction and strong dissolution due to the presence of more rigid grains and that fine sandstone generally undergoes strong compaction and cementation because of more plastic grains and high matrix content (Lai et al. 2018a, b). It has also been suggested that finer grain size is related to more matrix filling, resulting in more intense mechanical compaction, significant porosity loss and more intragranular micropore development within fine-grained tight sandstone (from fine sandstone to very fine sandstone and to coarse silt) (Shao et al. 2017).

Nevertheless, the previous studies focused on fine-grained sandstone were mostly qualitative, using thin-section methods and did not systematically reveal the lithologic controls on rock properties within the full ranges of rock types. The Shihezi Formation is presently the most significant reservoir of tight sandstone gas in the eastern Ordos Basin. It contains multiple rock types from pebbly coarse sandstone to siltstone, which lead to a diversity of pore-throat systems and strong heterogeneity of reservoir quality (Yue et al. 2018). This study aimed to investigate the lithological control on the pore structures and the quality of tight sandstone reservoir systematically using multiple methods, including thinsection analysis, scanning electron microscopy, nuclear magnetic resonance (NMR) and high-pressure mercury intrusion (HPMI) in the study area.

\section{Geological setting}

The study area is located in the northwestern margin of the Jinxi Fault-fold Belt in the Ordos Basin, which is the second largest sedimentary basin with vast oil, gas and coal in China (Fig. 1). The northern Ordos Basin was uplifted due to Hercynian movement during the Late Paleozoic and provided sediments for the basin fill. The corresponding sedimentary sequence consists of the Upper Carboniferous Benxi Sequence $\left(\mathrm{C}_{3} \mathrm{~b}\right)$, the Lower Permian Taiyuan Sequence $\left(\mathrm{P}_{1} \mathrm{t}\right)$ the Shanxi Sequence $\left(\mathrm{P}_{1} \mathrm{~s}\right)$, the Middle Permian Shihezi Sequence $\left(\mathrm{P}_{2} \mathrm{~h}\right)$ and the Upper Permian Shiqianfeng Formation $\left(\mathrm{P}_{3} \mathrm{q}\right)$ (Wang et al. 2008; Jia et al. 2017).

The Shihezi Formation $\left(\mathrm{P}_{2} \mathrm{~h}\right)$, primarily containing braided river delta sediments, is the target interval. $\mathrm{P}_{2} \mathrm{~h}$ is subdivided into eight parts. The $\mathrm{P}_{2} \mathrm{~h}$ sandstone is tight, with an average porosity and permeability of $7.75 \%$ and $0.77 \mathrm{mD}$ within the producing layers. Nevertheless, sweet spots with relatively high physical properties exist in the underwater distributary channels and river mouth bar. The $\mathrm{P}_{2} \mathrm{~h}$ reservoir has strong heterogeneity, as illustrated by its porosity and permeability, as well as varied pore types and structures observed in thin sections. Correspondingly, some wells yield a high gas flow, whereas others show little or no gas. The coal bed and shale within the $\mathrm{P}_{2} \mathrm{~s}, \mathrm{P}_{1} \mathrm{t}$ and $\mathrm{C}_{3} \mathrm{~b}$ are source rocks, which began to generate hydrocarbon at the end of the Triassic. The period from the Late Jurassic to the Early Cretaceous was the hydrocarbon expulsion peak and also was the primary reservoir-forming stage. The tectonic uplift that occurred during the stage from the Late Cretaceous to the present retarded the thermal evolution of the source rocks (Xie et al. 2016).

\section{Samples and methods}

According to the research objectives, samples from 16 wells covering a large range of lithologies from pebbly coarse sandstone to fine sandstone were collected from the $\mathrm{P}_{2} \mathrm{~h}$ tight gas sandstones in the eastern Ordos Basin, NW China. Particularly, 24 samples from 12 wells were measured by HPMI and proximal samples with the same depth were tested by NMR, in addition to other experiments (Table 1). The HPMI and NMR results were used to investigate the lithologic control on the pore structure and physical properties of the tight sandstones.

Routine core testing to measure the porosity and permeability of the $\mathrm{P}_{2}$ h tight sandstone was performed on 72 samples at $25^{\circ} \mathrm{C}$ and $35-50 \% \mathrm{RH}$. A PoroTm 300 porosimeter 


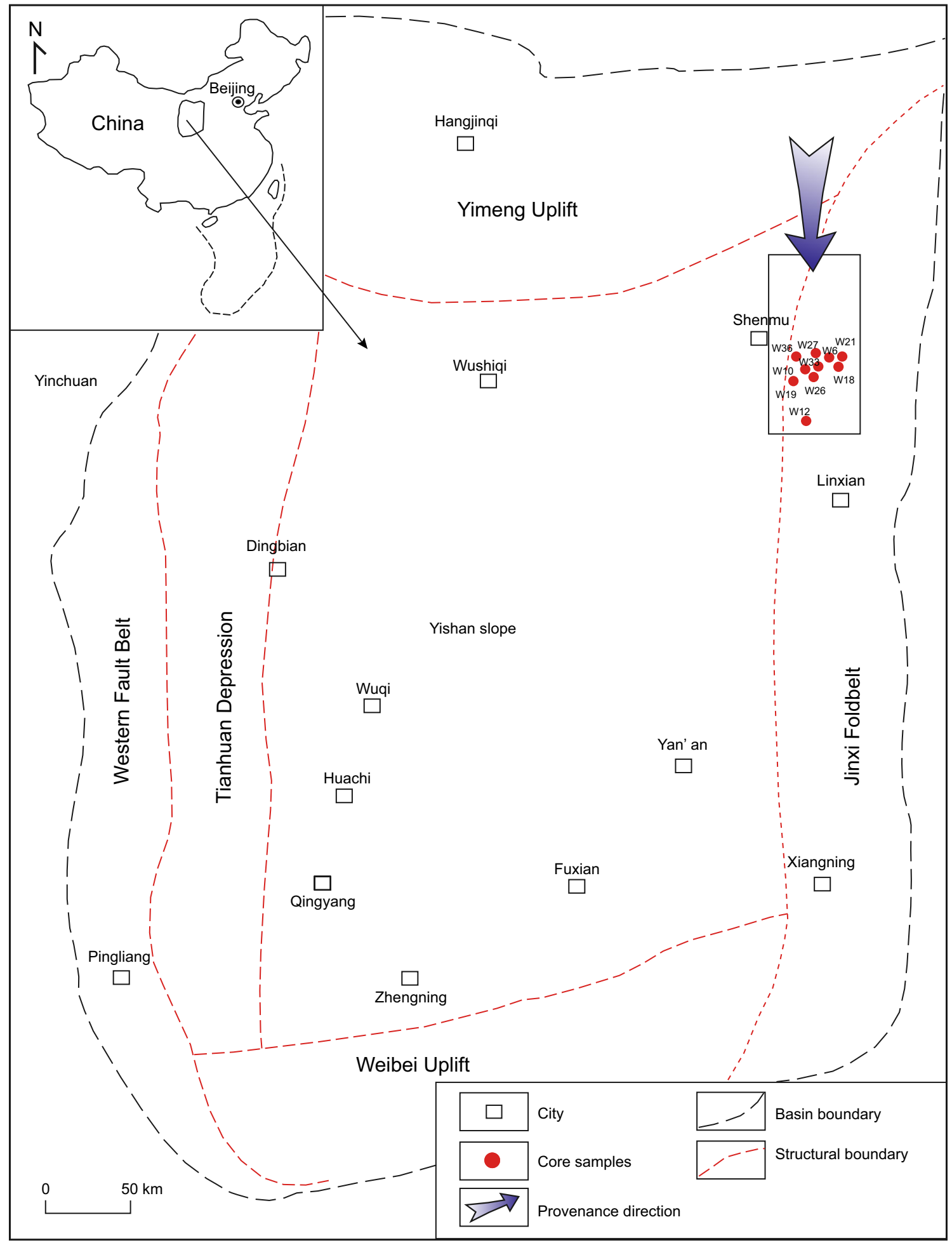

Fig. 1 Map of the Ordos Basin and location of the study area

and a low perm-meter with flowing air were used to obtain the porosity and permeability of these samples, respectively.

Seventy-two samples from 20 wells were cut to $2.54 \mathrm{~cm} \times 1.5 \mathrm{~cm} \times 0.5 \mathrm{~cm}$ volume for observation with the polarizing microscope. The thin-section chips were then casted with blue stain to highlight the pores (calcite stained with Alizarin Red S) using an LJS-3 casting machine and ground to thin sections by SPM-300 
Table 1 Representative samples and their primary parameters from HMPI

\begin{tabular}{|c|c|c|c|c|c|c|c|c|c|c|c|}
\hline \multirow{2}{*}{$\begin{array}{l}\text { Sample } \\
\mathrm{W} 19-1\end{array}$} & \multirow{2}{*}{$\begin{array}{l}\text { Depth, m } \\
1641.12\end{array}$} & \multirow{2}{*}{$\begin{array}{l}\text { Lithology } \\
\text { Pebbly coarse sandstone }\end{array}$} & \multirow{2}{*}{$\begin{array}{l}\text { Facies } \\
\text { Distributary channel }\end{array}$} & \multicolumn{2}{|c|}{$\begin{array}{l}\text { Porosity, \%/ } \\
\text { avg }\end{array}$} & \multicolumn{2}{|c|}{$\begin{array}{l}\text { Permeability, } \\
\mathrm{mD} / \text { avg }\end{array}$} & \multicolumn{2}{|c|}{$\begin{array}{l}\text { Displace- } \\
\text { ment pres- } \\
\text { sure, MPa/ } \\
\text { avg }\end{array}$} & \multicolumn{2}{|c|}{$\begin{array}{l}\text { Maximum } \\
\text { throat } \\
\text { radius, nm/ } \\
\text { avg }\end{array}$} \\
\hline & & & & 9.9 & 9.9 & 0.54 & 9.60 & 0.72 & 0.96 & 1.04 & 5.63 \\
\hline W21-1 & 1654.34 & Pebbly coarse sandstone & Channel lag & 16.0 & & 36.72 & & 0.04 & & 20.06 & \\
\hline W33-1 & 1371.67 & Pebbly coarse sandstone & Channel lag & 4.1 & & 0.67 & & 0.68 & & 1.10 & \\
\hline W33-2 & 1539.1 & Pebbly coarse sandstone & Channel lag & 9.5 & & 0.52 & & 2.40 & & 0.31 & \\
\hline W21-2 & 1757.78 & Coarse sandstone & Under water distributary channel & 15.2 & 14.6 & 4.85 & 3.06 & 0.20 & 0.36 & 3.81 & 2.42 \\
\hline W10-1 & 1480.4 & Coarse sandstone & Distributary channel & 18.6 & & 2.90 & & 0.39 & & 1.92 & \\
\hline W19-2 & 1521.27 & Coarse sandstone & Under water distributary channel & 12.8 & & 3.59 & & 0.29 & & 2.60 & \\
\hline W21-3 & 1759.84 & Coarse sandstone & Under water distributary channel & 11.6 & & 0.91 & & 0.56 & & 1.35 & \\
\hline W12 & 1791.13 & Pebbly medium sandstone & Under water distributary channel & 4.8 & 9.6 & 4.09 & 2.26 & 0.31 & 1.24 & 2.41 & 1.00 \\
\hline W18 & 1762.81 & Pebbly medium sandstone & Under water distributary channel & 5.6 & & 0.08 & & 2.28 & & 0.33 & \\
\hline W33-3 & 1360.83 & Pebbly medium sandstone & Channel lag & 18.1 & & 3.80 & & 1.12 & & 0.67 & \\
\hline W36 & 1656.85 & Pebbly medium sandstone & Under water distributary channel & 10.0 & & 1.06 & & 1.26 & & 0.60 & \\
\hline W6-1 & 1646.85 & Medium sandstone & Under water distributary channel & 6.0 & 8.7 & 0.39 & 1.74 & 1.02 & 0.92 & 0.72 & 0.92 \\
\hline W10-3 & 1484.1 & Medium sandstone & Distributary channel & 7.3 & & 0.22 & & 1.21 & & 0.62 & \\
\hline W10-2 & 1213.6 & Medium sandstone & Distributary channel & 5.1 & & 0.33 & & 0.98 & & 0.76 & \\
\hline W35 & 1442.47 & Medium sandstone & Distributary channel & 16.6 & & 6.02 & & 0.47 & & 1.57 & \\
\hline W30-1 & 1383.84 & Pebbly fine sandstone & Distributary channel & 11.5 & 10.5 & 2.30 & 1.57 & 0.83 & 0.91 & 0.90 & 1.16 \\
\hline W26-1 & 1603.1 & Pebbly fine sandstone & Distributary channel & 9.8 & & 1.33 & & 0.77 & & 0.98 & \\
\hline W26-2 & 1604.76 & Pebbly fine sandstone & Distributary channel & 10.5 & & 1.84 & & 0.65 & & 1.16 & \\
\hline W27 & 1547.75 & Pebbly fine sandstone & Under water distributary channel & 10.1 & & 0.79 & & 1.39 & & 0.15 & \\
\hline W6-2 & 1470.81 & Fine sandstone & Distributary channel & 3.0 & 8.5 & 0.23 & 0.51 & 0.33 & 1.09 & 2.22 & 1.20 \\
\hline W21-4 & 1651.12 & Fine sandstone & Point bar & 11.3 & & 0.16 & & 2.21 & & 0.34 & \\
\hline W30-2 & 1447.37 & Fine sandstone & Distributary channel & 11.2 & & 1.13 & & 0.73 & & 1.03 & \\
\hline
\end{tabular}

W26-1, W26-2, and W6-2 have no corresponding NMR test

double-deck grinding machine. Finally, petrologic investigation of these samples was conducted using a DMLP polarizing microscope at the test temperate and humidity of $25{ }^{\circ} \mathrm{C}$ and $40 \%$, respectively. The detailed procedure was referred from the China Petroleum and Natural Gas Industry Standard SY/T 5913-2004. In addition, 24 samples, each weighting 10-12 g, were crushed to radii smaller than $1 \mathrm{~mm}$. Then, a D/max-2200 powered X-ray diffractometer was employed for X-ray diffraction testing (XRD) of mineral compositions, and the absolute and relative contents of clay minerals of these samples following SY/T 5163-2010.

Field-emission scanning electron microscopy (FESEM) analysis of 72 samples was performed using a JSM-5500LV scanning electron microscope, equipped with a QUANTAX400 energy-dispersive X-ray spectrophotometer following SY-T5162-1997. Small samples were cut from large core samples (diameter $=1 \mathrm{~mm}$, thickness $=1 \mathrm{~mm}$ ) and then were analyzed at a temperature of $25^{\circ} \mathrm{C}$ and humidity level of $40 \%$. The SEM micrographs, with magnifications ranging from 100 to 15,000 under
$20 \mathrm{kV}$, could provide critical information on the size, morphology and even connectivity of pores.

The pore-throat distribution was investigated by HPMI using an AutoPore IV9500 mercury porosimeter at $18.9-19.8{ }^{\circ} \mathrm{C}$ following SY/T 5346-2005. Twentyfour samples from 12 wells (diameter $=2.53 \mathrm{~cm}$, length $=2.5 \mathrm{~cm}$ ), with six diverse lithologies (from pebbly coarse sandstone to fine sandstone), were measured. Pore-throat structure was characterized according to the patterns of the mercury intrusion and extrusion curves. The permeability contribution distribution was also acquired from the fluid flow capacity for different pore-throat radii using Eq. (1). The method can be specifically followed the work of Wall (1965).

$c=\frac{(2 i-1) \times r_{n}^{2}}{\sum_{i=1}^{n}(2 i-1) \times r_{n}^{2}} \times 100$

In Eq. (1), $c$ is the permeability contribution of pores with the same radius, $n$ is the group of pores divided on the basis of pore size, and $r_{n}$ is the pore radius $(\mu \mathrm{m})$. 
Low-field NMR technology is now used increasingly to characterize the pore size distribution (PSD) within unconventional reservoirs. The NMR $T_{2}$ relaxation time can be applied to indicate the PSD of tight sandstone. $T_{2}$ is controlled by three relaxation mechanisms, the surface, bulk and diffusion relaxations.

The bulk relaxation can be neglected because it takes a longer amount of time than the surface relaxation for nonviscous kerosene. The diffusion relaxation can also be ignored in a low and uniform magnetic field. Thus, the NMR $T_{2}$ relaxation time is primarily determined by the surface relaxation (Eq. 2):

$\frac{1}{T_{2}}=\rho_{2} \frac{S}{V}$

Twenty-two samples of six different lithologies (diameter $=2.54 \mathrm{~cm}$, length $=2.54 \mathrm{~cm}$ ) were selected for NMR $T_{2}$ distribution determination after crude oil and salt contamination were removed using an NMR rock core analyzer. The NMR parameters were as follows: waiting time, $3 \mathrm{~s}$; echo spacing, $0.6 \mathrm{~ms}$; number of scans, 256; echo numbers, 1024; water salinity, $49,600 \mathrm{mg} / \mathrm{g}$, experimental temperature $35{ }^{\circ} \mathrm{C}$.

\section{Results and discussion}

\subsection{Rock types, mineral compositions and pore systems}

The bulk-rock mineralogy obtained by thin-section observation demonstrated that samples of $\mathrm{P}_{2} \mathrm{~h}$ were mainly feldspathic litharenites and lithic arkoses (Fig. 2). The upper Shihezi Formation had less feldspar and more rock fragments than the lower Shihezi Formation. As shown in Fig. 3, quartz, metamorphic rock fragments and potash feldspar were three the primary compositions within the $\mathrm{P}_{2} \mathrm{~h}$ reservoir. Nevertheless, as illustrated in Fig. 4, the pebbly sandstones (pebbly coarse sandstone, pebbly medium sandstone and pebbly fine sandstone) contained less quartz and more metamorphic rock fragments, volcanic rock fragments and plagioclase than the non-pebbly sandstones (coarse sandstone, medium sandstone and fine sandstone). Pebbly coarse sandstone had the largest content of feldspar (plagioclase and potash feldspar), whereas medium sandstone had the lowest feldspar but highest quart content. Among the pebbly sandstones, pebbly fine sandstone had the more quartz and metamorphic rock fragments, but less plagioclase. The nonpebbly sandstones showed similar compositions, except that volcanic rock fragments increase as the lithology became finer.

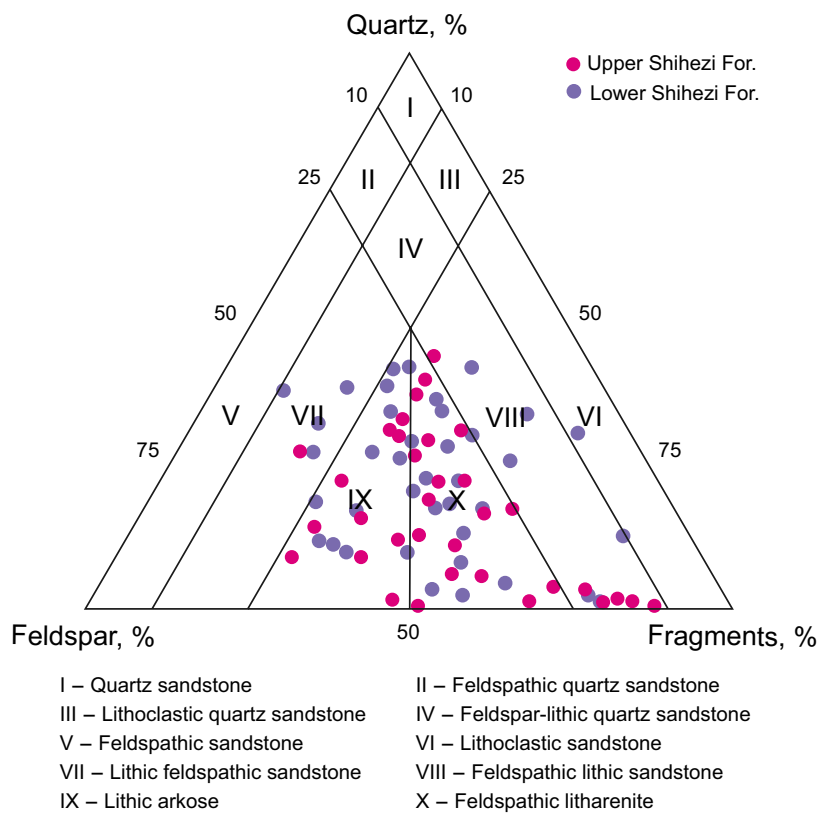

Fig. 2 Rock type of the tight sandstone of $\mathrm{P}_{2} \mathrm{~h}$ reservoir

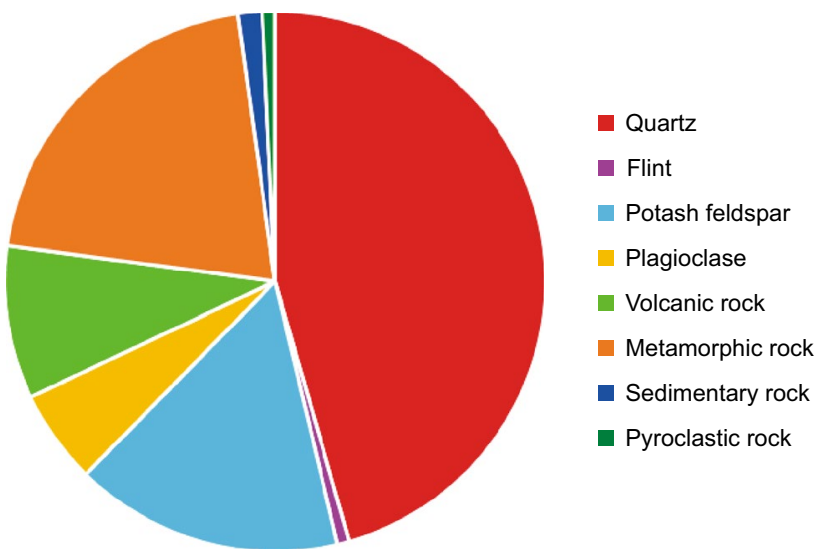

Fig. 3 Rock compositions of the $\mathrm{P}_{2} \mathrm{~h}$ tight sandstone reservoir

The content of interstitial fillings (including clay minerals and cements) increased as grain size became smaller, except for the medium sandstone (Fig. 5). The reason that the fine sandstone contained more interstitial fillings is that it has more cement and lower clay mineral content. Figure 6 illustrates that most samples contained interstitial fillings less than $15 \%$. Nevertheless, some samples of pebbly fine sandstone and fine sandstone had a larger content of interstitial fillings with some samples exceeding $30 \%$. Overall, $5-10 \%$ and $10-15 \%$ were the primary distribution intervals of all samples. However, it varied with grain size. The main distribution interval of pebbly coarse sandstone was $5-10 \%$, whereas both coarse sandstone and fine sandstone contained interstitial fillings with a peak interval of $10-15 \%$. 

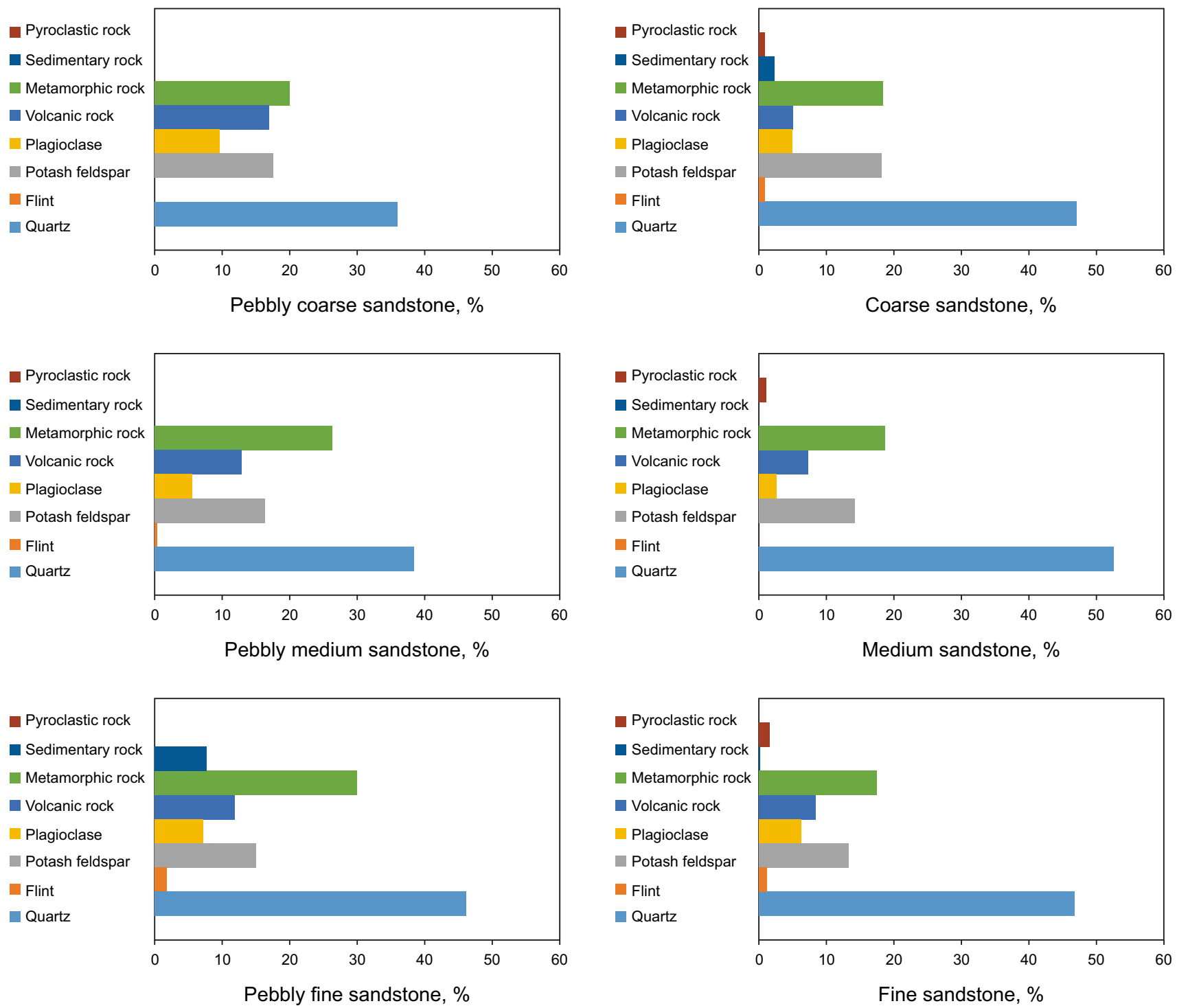

Fig. 4 Rock compositions for 24 samples with diverse lithologies obtained from thin sections

The pebbly medium sandstone, medium sandstone and pebbly fine sandstone had relatively less content of interstitial fillings, with a primary distribution of $5-10 \%$.

As illustrated in Fig. 6b, smectite was not developed within the coarse-grained reservoir in this area. The clay mineral composition varied greatly among these samples of different lithologies. The pebbly coarse sandstone had the lowest contents of illite and kaolinite and the highest illite/smectite-mixed layer $(I / S)$ content (exceeding 55\%), whereas the medium sandstone contained the highest percentage of kaolinite and lowest percentage of $I / S$. The pebbly fine sandstone had the highest chlorite/smectite-mixed layer $(C / S)$ content of about $20 \%$. The chlorite content was more stable among all lithologies, with an average content of approximately $30 \%$.
The casting thin-section and scanning electron microscope analysis provided additional visual details of the characteristics of pore types and structures, as shown in Fig. 7. The $\mathrm{P}_{2} \mathrm{~h}$ tight sandstone primarily contained four pore types: residual intergranular pores, intergranular dissolution pores, intragranular dissolution pores and intercrystalline pores. Plenty of intragranular dissolution pores and intergranular dissolution pores were developed in the pebbly coarse sandstone (Fig. 7a-c), although these were frequently mixed with residual intergranular pores (Fig. 7c). The intergranular dissolution pores, ranging in size from 10 to $200 \mu \mathrm{m}$, were commonly developed within the feldspar and rock fragment. The combination of intragranular pores and fractures within feldspar could largely improve the physical properties (Fig. 7b). Nevertheless, there were more residual intergranular pores within the coarse sandstone 


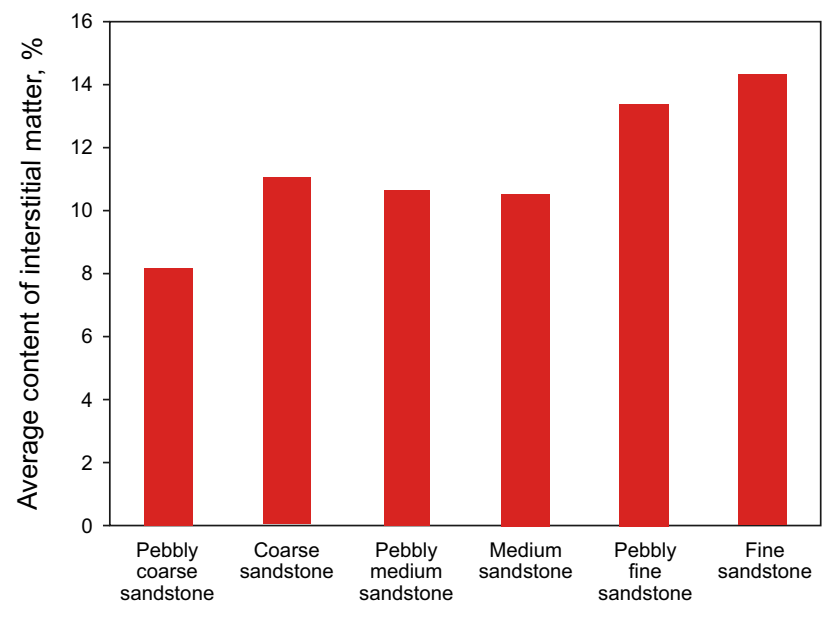

Fig. 5 Average interstitial fillings contents of 72 samples with diverse lithologies obtained from thin-section analysis

in addition to intergranular dissolution pores and intragranular dissolution pores (Fig. 7d-f). The residual intergranular pores might contribute to the large porosity and permeability of the four samples of coarse sandstone. The intergranular dissolution pores were as large as $400 \mu \mathrm{m}$ in long dimension and maybe developed with intragranular dissolution pores (Fig. 7d). The size of the dissolution pores was identical to that of the pebbly coarse sandstone, with a range of 20-200 $\mu \mathrm{m}$. The medium sandstone of $\mathrm{P}_{2} \mathrm{~h}$ reservoir had a large amount of intergranular and intragranular dissolution pores and some residual intergranular pores (Fig. $7 \mathrm{~g}-\mathrm{i}$ ). Nevertheless, the size of the intergranular dissolution pores and the intragranular dissolution pores (range of 10-100 $\mu \mathrm{m}$ ) was smaller than that of the pebbly coarse sandstone and coarse sandstone. However, the pore number of the medium sandstone was larger than that of the latter two sandstones. Unlike the case of the pebbly coarse sandstone and coarse sandstone, intercrystalline pores, particularly pores between kaolinite (Fig. 7i), contributed a rather large portion of the total porosity in the medium sandstone.

There were relatively few intergranular dissolution pores, intragranular dissolution pores and residual intergranular pores within the samples of fine sandstone (Fig. 7j, k), because the fine sandstone was tightly cemented (Fig. 7k). This phenomenon may account for the low porosity and permeability within the fine sandstone reservoirs. However, a large amount of intercrystalline pores was developed within the fine sandstone samples, as shown in Fig. 7i.

\subsection{Lithological control on the physical properties of the tight sandstone}

The porosity varied with grain size, as shown in Fig. 7c. Although the pebbly coarse sandstone contained the highest amount of clay minerals, it had the largest porosity, with an average value of $13 \%$. This likely resulted from the lower cement content. The medium sandstone had the second largest porosity, exceeding $10 \%$ on average, whereas the fine sandstone had the lowest porosity. Figure $7 \mathrm{~d}$ also shows that the pebbly coarse sandstone and the medium sandstone had the largest proportions of large pore, exceeding 10\% and $20 \%$, respectively. The peak porosity intervals of the pebbly coarse sandstone, coarse sandstone, pebbly medium sandstone and pebbly fine sandstone were $10-14 \%$, whereas that of the fine sandstone was $6-10 \%$. The medium sandstone had no obvious peak interval and the content of each portion exceeded $20 \%$, showing strong heterogeneity of porosity distribution. Analogously, the pebbly coarse sandstone and medium sandstone also had the highest average permeability values (Fig. 7e). The fine sandstone had the lowest average permeability. The medium sandstone had the second largest average permeability value of approximately $0.06 \mathrm{mD}$. All samples, except for fine sandstone, had a large proportion of high-permeability interval (Fig. 7f), especially in the case of the pebbly coarse sandstone ( $>50 \%)$. The permeability of the fine sandstone was lowest, primarily between $0.01-0.1 \mathrm{mD}$ and $0.1-0.5 \mathrm{mD}$. Similar to the distribution of porosity, the permeability of the medium sandstone was also relatively uniform, with a high percentage of $0.01-0.1 \mathrm{mD}$ interval (>30\%). In addition, a good relationship between porosity and permeability occurred for all lithologies, as shown in Fig. 8, and there was no obvious diversity of the relationship law among the different lithologies.

The impact of clay minerals on the porosity and permeability was also a concern of previous studies (Zhou et al. 2016). The relationships between clay minerals and porosity and permeability in the study area were nonlinear and complex. As shown in Fig. 9, illite content first increased and then decreased with increase in porosity. Nevertheless, illite content was negatively correlated with permeability. Chlorite content was a little positively correlated with porosity and permeability. I/S content was weakly positively associated with porosity.

\subsection{Pore size distributions of the different lithologies}

As shown by the mercury intrusion/extrusion curves for the samples (Fig. 10a-f), the pore-throat structure of each lithology showed diversity to some extent. Nevertheless, the pebbly coarse sandstone and coarse sandstone had obviously lower displacement pressure and larger maximum connected pore-throat radius (MCPR). The coarse sandstone had a lower average value of displacement pressure $(0.36 \mathrm{MPa})$ than the pebbly coarse sandstone (0.96 MPa) because all four samples of the coarse sandstone had good physical properties. The worst sample of these had porosity and permeability values of $11.6 \%$ and 

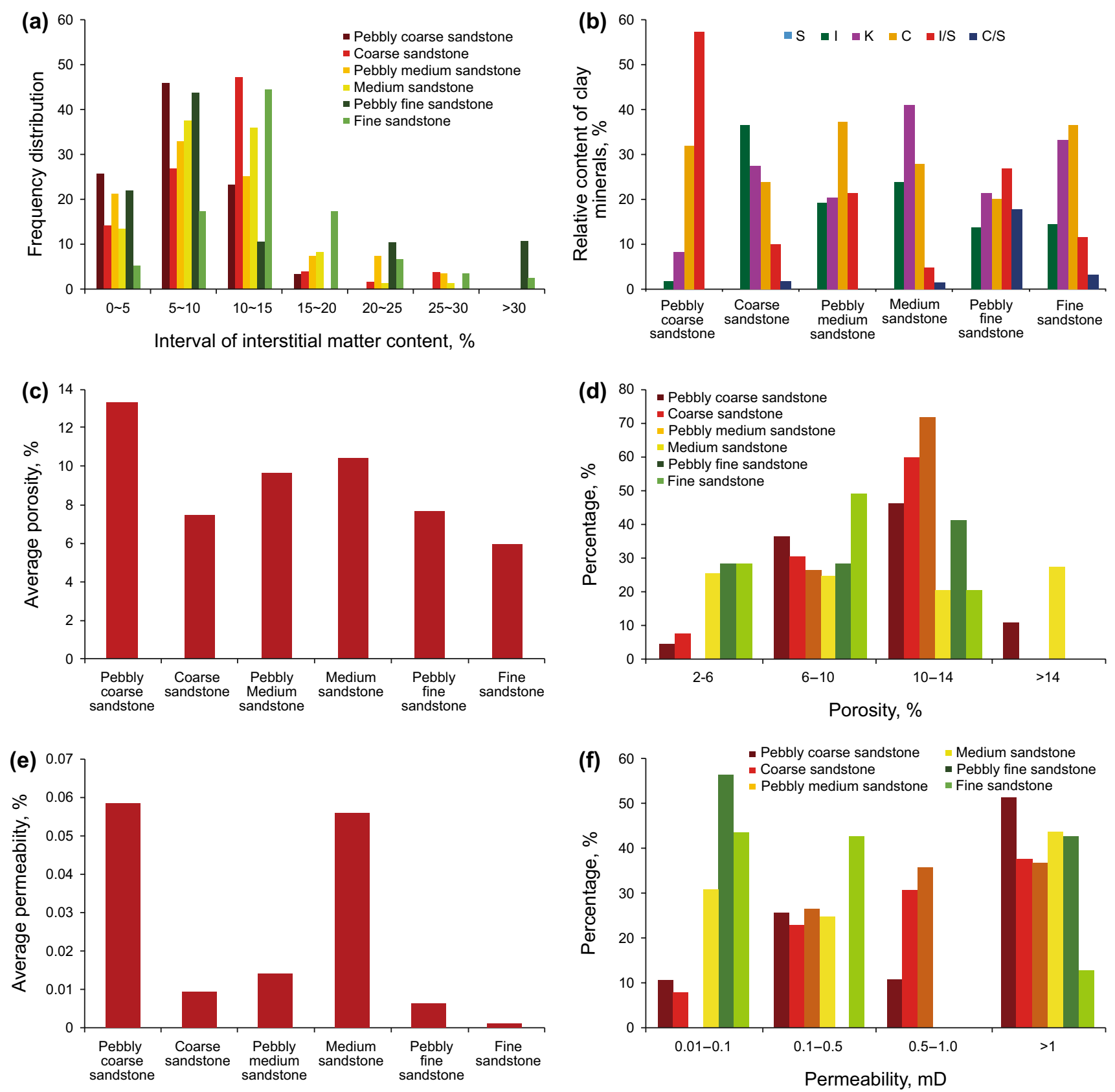

Fig. 6 a Frequency distributions of interstitial fillings for 72 samples with diverse lithologies; b clay mineral compositions for 24 samples with diverse lithologies; $\mathbf{c}$ average porosity for 72 samples with diverse lithologies; $\mathbf{d}$ distribution of porosity for different lithologies; e average permeability for 72 samples with diverse lithologies; $\mathbf{f}$ distribution of permeability for different lithologies

$0.91 \mathrm{mD}$, respectively. The pebbly medium sandstone and medium sandstone had the largest diversity of mercury saturation, with a range of $19-82 \%$, showing the greatest heterogeneity. The pebbly fine sandstone and fine sandstone had relatively low porosity and permeability, as well as low MCPR. Their mercury saturations varied the least, demonstrating the weakest heterogeneity among all lithologies, although these lithologies had a variation range of $20 \%$ and $12 \%$, respectively.
The high porosity within the coarser sandstones was generally contributed by large pores (Fig. 11a, b), whereas the porosity in samples with small grain size was more likely due to a large amount of small pores (Fig. 11c-f), although some excepts existed (W30-1 in Fig. 11e). As shown in Fig. 11, according to the Windland R35 method (Kolodzie 1980), coarse sandstone (W19-2) and medium sandstone (W10-3) had larger R35 values in a range of $0.5-2 \mu \mathrm{m}$ and belonged to "Mesoport" type, whereas other sandstones 

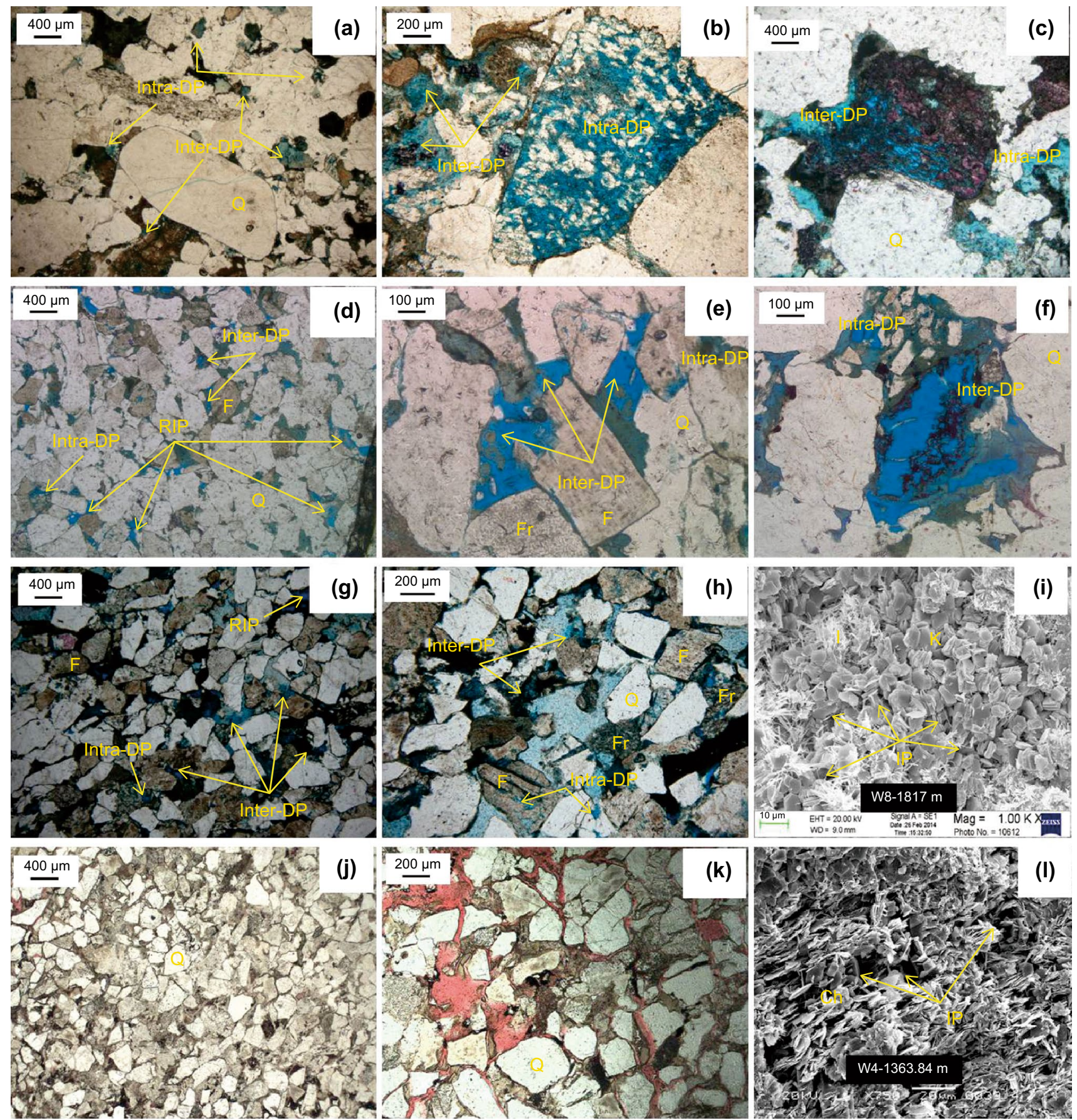

Fig. 7 Photomicrographs showing the pore types within the $\mathrm{P}_{2} \mathrm{~h}$ tight sandstone: $\mathbf{a}, \mathbf{b}$ intergranular dissolution pores (Inter-DP) and intragranular dissolution pores (Intra-DP) within the pebbly coarse sandstone, PPL, W8, $1797 \mathrm{~m}$; $\mathbf{c}$ Inter-DP and Intra-DP within the pebbly coarse sandstone, PPL, W19, $1641.12 \mathrm{~m}$; d residual intergranular pores (RIP), Inter-DP and Intra-DP within the coarse sandstone, PPL, W21, 1759.75 m; e InterDP and Intra-DP within the coarse sandstone, PPL, W21, $1759.75 \mathrm{~m}$; f Inter-DP and Intra-DP within the coarse sandstone, PPL, W21, 1628.4 m; g RIP, Inter-DP and Intra-DP within the medium sandstone, PPL, W10, 1406.5 m; h Inter-DP and Intra-DP within the medium sandstone, PPL, W10, $1406.5 \mathrm{~m}$; i intercrystalline pores within Kaolinite in the medium sandstone, SEM, W8, $1817 \mathrm{~m}$; j strong compaction in the fine sandstone with fewer pores, PPL, W4, $1305.5 \mathrm{~m}$; $\mathbf{k}$ calcite cementation in the fine sandstone, PPL, W4, $1305.5 \mathrm{~m} ; \mathbf{l}$ intercrystalline pores within chlorite in the fine sandstone, SEM, W4, $1363.84 \mathrm{~m}$. $P P L$ plane polarized light, $Q$ quartz, $F$ feldspar, $F r$ rock fragment, $I$ illite, $K$ kaolinite, $C h$ chlorite, $R I P$ residual intergranular pore, Inter- $D P$ intergranular dissolution pore, Intra- $D P$ intragranular pore, $I P$ intercrystalline pore 


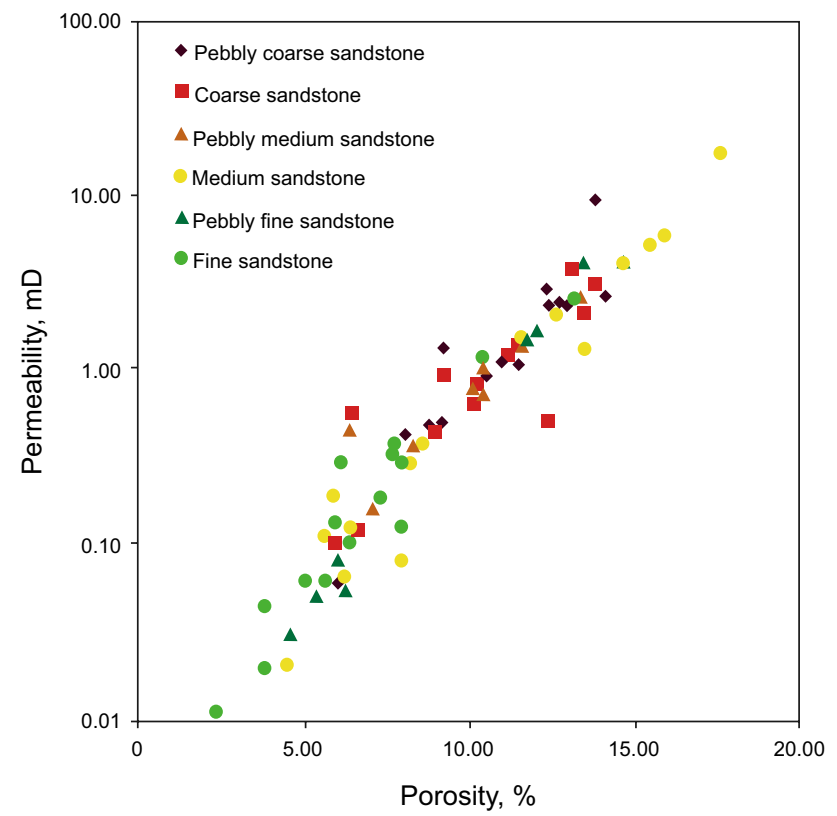

Fig. 8 Relationship between porosity and permeability for samples with diverse lithologies

had R35 values in a range of $0.1-0.5 \mu \mathrm{m}$ belonged to "Microport" type.

The $T_{2}$ spectra for samples with diverse lithologies in the study area were not identical. Additionally, there was a difference between the $T_{2}$ distributions of the same lithology. Overall, the $T_{2}$ distributions of pebbly coarse sandstone, coarse sandstone, pebbly medium sandstone and medium sandstone showed a wide distribution and large signal amplitude, which were around $0.1-1000 \mathrm{~ms}$ and $0.6-1.1 \%$, respectively (Fig. 12a-c). The maximum values of the $T_{2}$ distributions and signal amplitudes of pebbly fine sandstone and fine sandstone were approximately $400 \mathrm{~ms}$ and $0.63 \%$, respectively, indicating a lower porosity within this type of reservoir (Fig. 12e, f). Therefore, similar to the HPMI results, the reservoirs with large grain sizes tended to have high porosity and vice versa. In addition, the medium sandstone had the largest difference of $T_{2}$ distributions, with a signal amplitude range of $0.15-1.2 \%$ (Fig. 12d). The NMR results also reveal the pore size distribution and connectivity of pores. Most of the samples had two peaks in the $T_{2}$ distribution. The first peak with a smaller $T_{2}$ relaxation time represented small pores, and the second peak corresponding to a larger $T_{2}$ relaxation time indicated large pores. Although the coarser sandstones had high porosity on the whole, the $T_{2}$ relaxation times of the first peak of all of the samples were all located within a relatively narrow range of $0.8-1.5 \mathrm{~ms}$. The samples with large porosity had a $T_{2}$ relaxation time of the first peak of $1.2-1.5 \mathrm{~ms}$, and those with relatively small porosity had a smaller $T_{2}$ relaxation time corresponding to the first peak of approximately $0.8-1.2 \mathrm{~ms}$. Unlike the first peak of the $T_{2}$ relaxation time, the second peak had a rather wide range of $T_{2}$ time of $10-110 \mathrm{~ms}$. The pebbly coarse sandstone, coarse sandstone and pebbly medium sandstone had a large $T_{2}$ time value of the second peak, greater than $100 \mathrm{~ms}$. Conversely, the other sandstones with smaller grain size had a $T_{2}$ time value of the second peak of 10-100 ms, with an average of $50 \mathrm{~ms}$. Additionally, strong heterogeneity existed within each lithological group. In the pebbly medium sandstone group, the four samples had entirely different $T_{2}$ distributions. The $\mathrm{W} 18$ sample had a narrow $T_{2}$ time distribution of $0.1-100 \mathrm{~ms}$, a small signal amplitude of $0.26 \%$ and a rather small second peak corresponding to a signal amplitude of $0.6 \%$. However, the W12 and W33-3 samples had a wide $T_{2}$ time distribution of $0.1-1100 \mathrm{~ms}$ and large signal amplitude of $0.4-0.6 \%$. The latter even had a second peak with larger signal amplitude than the first peak. Unlike these three types, the $T_{2}$ distribution of W36 was unimodal with a large-signal amplitude of $0.5 \%$.

The connectivity between the two peaks was diverse within each group. The samples with large porosity and permeability, such as the W21-1 in the pebbly coarse sandstone group, the W19-2 and W21-2 in the coarse sandstone group, the W12 in the pebbly medium sandstone, the W30-1 in the pebbly fine sandstone group and the W30-2 in the fine sandstone group generally had better connectivity of the two peaks. However, the good connectivity between small pores and larger pores did not indicate large permeability, such as for W35 in the medium sandstone group. Previous studies showed that permeability was mainly related to large pores and that the MCPR from HPMI may indicate permeability more accurately ${ }^{35}$. Therefore, the connectivity between two peaks from NMR is not an ideal indicator of rock permeability.

\subsection{Comparison of pore size distribution between coarse sandstones and fine sandstones}

Zhu et al. (2018) analyzed the distribution of pore size of fine-grained samples in the southwestern Ordos Basin, including the fine sandstone, very fine sandstone and coarse siltstone, using NMR and thin sections. These samples contained more quartz and feldspars and less interstitial material. The amount of cements was less than that of the coarsegrained samples in this area. In addition, the porosity of the fine-grained samples was also much lower. The $T_{2}$ distributions of the fine samples had a narrower body and lower peak value. The porosity at the radii connecting two peaks was almost lower than 0.1 within the fine-grained samples, whereas the value was larger than 0.2 within most coarsegrained samples. Therefore, by integrating the two aspects, it can be concluded that the fine-grained reservoir tends to have poor pore structure and correspondingly low porosity and permeability, except for the medium sandstone. 

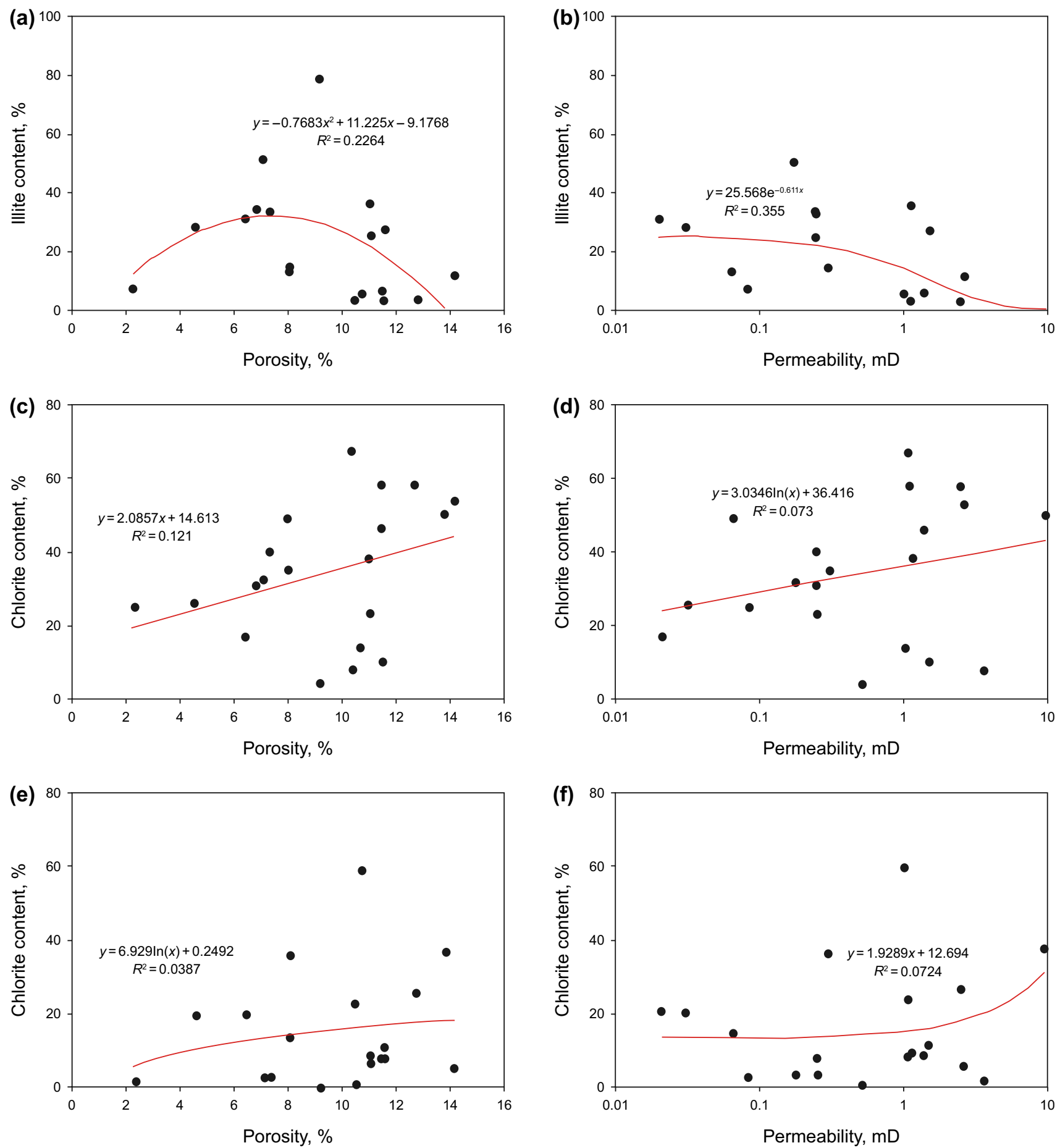

Fig. 9 Plots showing the relationship between a illite content and porosity, $\mathbf{b}$ illite content and permeability, $\mathbf{c}$ kaolinite content and porosity, $\mathbf{d}$ kaolinite content and permeability, $\mathbf{e}$ chlorite content and porosity, $\mathbf{f}$ chlorite content and permeability, $\mathbf{g}$ andreattite content and porosity, $\mathbf{h}$ andreattite content and permeability

\section{Conclusion}

A series of experiments were conducted to investigate the lithological control on the pore structures and physical properties of the $\mathrm{P}_{2} \mathrm{~h}$ tight sandstone reservoir in the eastern
Ordos Basin. This reservoir has strong heterogeneity in the aspects of both macroscopic porosity and permeability and microscopic pore-throat structures within all types of rock. Although many of the sandstone samples were fairly tight, some types of reservoirs with relatively high 

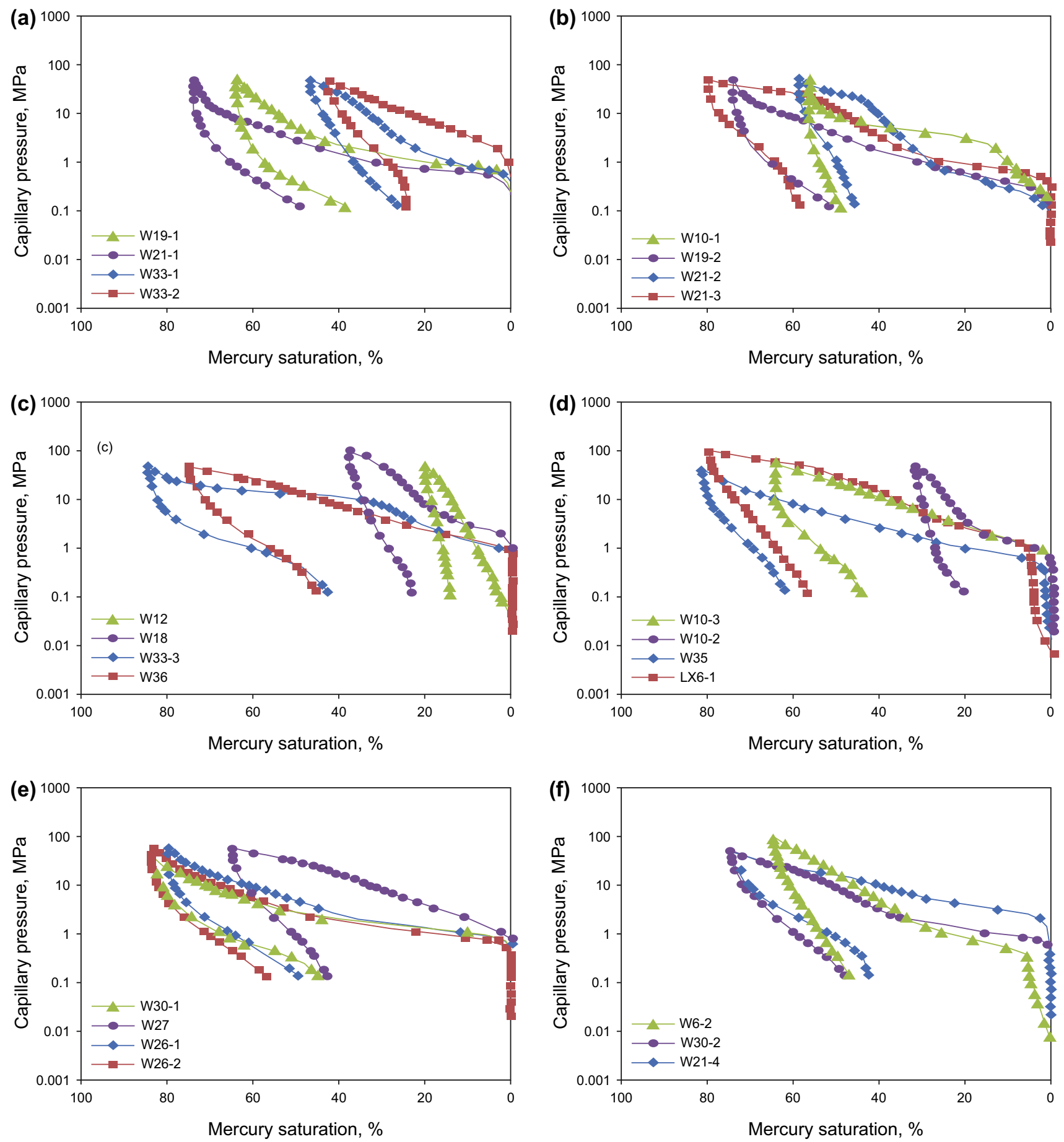

Fig. 10 Mercury injection curves for the samples of a pebbly coarse sandstone, $\mathbf{b}$ coarse sandstone, $\mathbf{c}$ pebbly medium sandstone, $\mathbf{d}$ medium sandstone, e pebbly fine sandstone, $\mathbf{f}$ fine sandstone

average porosity and permeability can be viewed as spot sweets, such as pebbly coarse sandstone, coarse sandstone and medium sandstone reservoirs. Nevertheless, the medium sandstone reservoir has the strongest heterogeneity, which may bring some risks of tight sandstone gas exploration and development.
The $\mathrm{P}_{2} \mathrm{~h}$ tight sandstone contains mainly intergranular dissolution pores, intragranular dissolution pores and intercrystalline pores. The former is as large as $200 \mu \mathrm{m}$. Some coarser-grained samples had a small amount of residual 

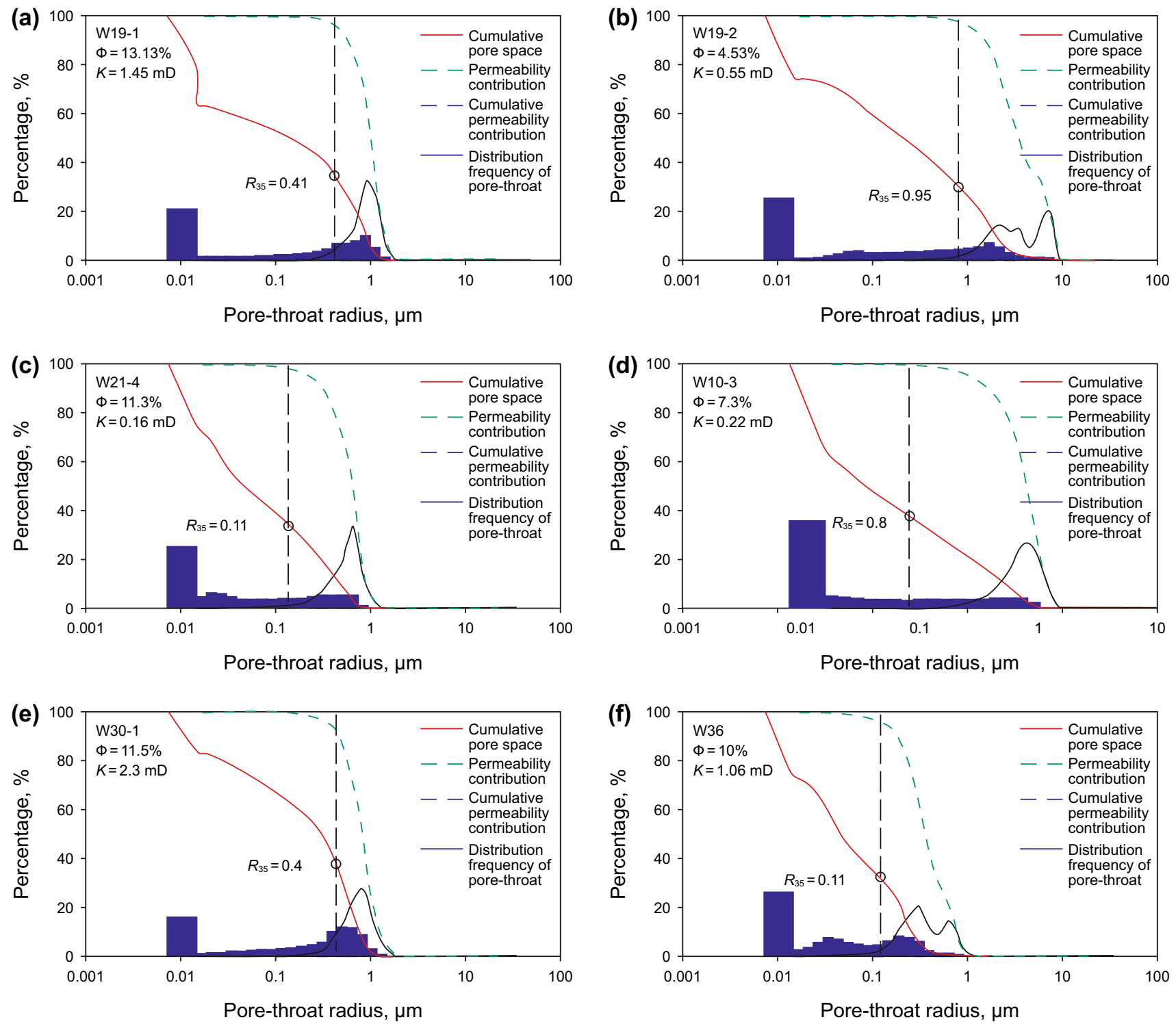

Fig. 11 Pore size distribution (PSD) and its contributions to porosity and permeability for samples of a pebbly coarse sandstone, $\mathbf{b}$ coarse sandstone, $\mathbf{c}$ pebbly medium sandstone, $\mathbf{d}$ medium sandstone, $\mathbf{e}$ pebbly fine sandstone and $\mathbf{f}$ fine sandstone

intergranular pores. The coarse sandstone and medium sandstone contain relatively large intragranular dissolution pores, whereas the fine sandstone has more intercrystalline pores with a more homogeneous pore structure.

As the $T_{2}$ spectra from the NMR and HPMI showed, the coarse-grained sandstones tend to have large pores and throat radii, whereas the fine-grained sandstones generally have more small pores and throat radii. Large pores contribute most to the permeability within all samples. Nevertheless, small pores in the fine-grained sandstones contribute more to the porosity than small pores in the coarse-grained sandstone. 

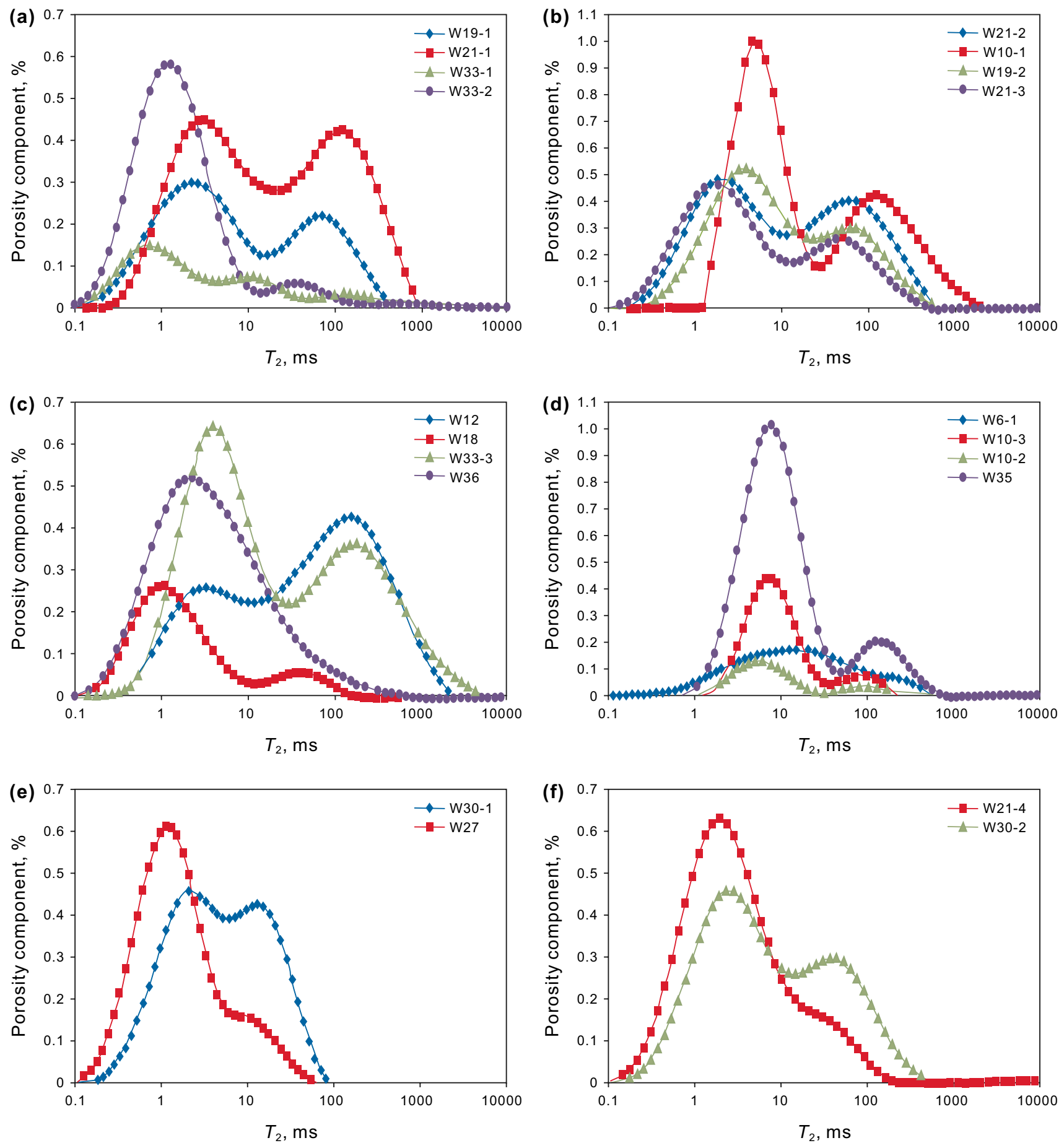

Fig. $12 T_{2}$ distributions for samples of a pebbly coarse sandstone, $\mathbf{b}$ coarse sandstone, $\mathbf{c}$ pebbly medium sandstone, $\mathbf{d}$ medium sandstone, $\mathbf{e}$ pebbly fine sandstone and $\mathbf{f}$ fine sandstone

Acknowledgements This study was funded by the National Science and Technology Major Project (2016ZX05061-003-001), Major Project of CNOOC (CNOOC-KJ135ZDXMLTD14) and National Natural Science Foundation of China $(41672116,41672125)$. We thank the experts at the CNOOC for providing the samples and data. We also thank Dianshi Xiao for suggestions that improved the paper.
Open Access This article is licensed under a Creative Commons Attribution 4.0 International License, which permits use, sharing, adaptation, distribution and reproduction in any medium or format, as long as you give appropriate credit to the original author(s) and the source, provide a link to the Creative Commons licence, and indicate if changes were made. The images or other third party material in this article are included in the article's Creative Commons licence, unless indicated 
otherwise in a credit line to the material. If material is not included in the article's Creative Commons licence and your intended use is not permitted by statutory regulation or exceeds the permitted use, you will need to obtain permission directly from the copyright holder. To view a copy of this licence, visit http://creativecommons.org/licenses/by/4.0/.

\section{References}

Anovitz LM, Cole DR. Characterization and analysis of porosity and pore structures. Rev Mineral Geochem. 2015;80(1):61-164. https ://doi.org/10.2138/rmg.2015.80.04.

Anovitz LM, Cole DR, Rother G, et al. Diagenetic changes in macroto nano-scale porosity in the St. Peter Sandstone: an (ultra) small angle neutron scattering and backscattered electron imaging analysis. Geochim Cosmochim Acta. 2013;102:280-305. https://doi. org/10.1016/j.gca.2012.07.035.

Anovitz LM, Cole DR, Jackson AJ, et al. Effect of quartz overgrowth precipitation on the multiscale porosity of sandstone: a (U)SANS and imaging analysis. Geochim Cosmochim Acta. 2015;153:199222. https://doi.org/10.1016/j.gca.2015.01.028.

Bjørlykke K, Jahren J. Open closed geochemical systems during diagenesis in sedimentary basins: constraints on mass transfer during diagenesis and the prediction of porosity in sandstone and carbonate reservoirs. AAPG Bull. 2012;96(12):2193-214. https ://doi.org/10.1306/04301211139.

Chen GY, Luo J, Luo YC, et al. Characteristics of tight sandstone gas reservoir distribution under control of sedimentary facies: a case study from the penglaizhen formation in the central western Sichuan depression. Oil Gas Geol. 2017;38(3):467-77 (in Chinese).

Clarkson CR, Freeman M, He L, et al. Characterization of tight gas reservoir pore structure using USANS/SANS and gas adsorption analysis. Fuel. 2012a;95(1):371-85. https://doi.org/10.1016/j. fuel.2011.12.010

Clarkson CR, Jensen JL, Pedersen PK. Innovative methods for flowunit and pore-structure analyses in a tight siltstone and shale gas reservoir. AAPG Bull. 2012b;96(2):355-74. https://doi. org/10.1306/05181110171.

Feng WT, Patrick W, Li MT, et al. Numerical study on hydraulic fracturing in tight gas formation in consideration of thermal effects and THM coupled processes. J Pet Sci Eng. 2016;146:241-54. https://doi.org/10.1016/j.petrol.2016.04.033.

Guo $\mathrm{CH}, \mathrm{Xu}$ JC, Wei MZ, et al. Experimental study and numerical simulation of hydraulic fracturing tight sandstone reservoirs. Fuel. 2015;159:334-44. https://doi.org/10.1016/j. fuel.2015.06.057.

Huang HX, Sun W, Ji WM, et al. Effects of pore-throat structure on gas permeability in the tight sandstone reservoirs of the upper triassic Yanchang formation in the western Ordos Basin, China. J Nat Gas Sci Eng. 2018;162:602-16. https://doi.org/10.1016/j. petrol.2017.10.076.

Jia CY, Jia AL, Zhao X, et al. Architecture and quantitative assessment of channeled clastic deposits, Shihezi sandstone (lower Permian), Ordos Basin, China. Nat Gas Sci Eng. 2017;2(1):1120. https://doi.org/10.1016/j.jnggs.2017.01.002.

Kolodzie S. Analysis of pore throat size and use of the WaxmanSmits equation to determine OOIP in Spindle Field, Colorado. SPE paper 1980; 9382.

Lai J, Wang GW, Ran Y, et al. Predictive distribution of high-quality reservoirs of tight gas sandstones by linking diagenesis to depositional facies: evidence from $\mathrm{xu}-2$ sandstones in the Penglai area of the central Sichuan Basin, China. J Nat Gas Sci Eng. 2015;23:97-111. https://doi.org/10.1016/j.jngse.2015.01.026.

Lai J, Wang G, Fan Z, et al. Insight into the pore structure of tight sandstones using NMR and HPMI measurements. Energy Fuels. 2016;30:10200-14. https://doi.org/10.1021/acs.energyfuel s.6b01982.

Lai J, Wang GW, Cao JT, et al. Investigation of pore structure and petrophysical property in tight sandstones. Mar Pet Geol. 2018a;91:179-89. https://doi.org/10.1016/j.marpe tgeo.2017.12.024.

Lai J, Wang GW, Wang ZY, et al. A review on pore structure characterization in tight sandstones. Earth Sci Rev. 2018b;177:436-57. https://doi.org/10.1016/j.earscirev.2017.12.003.

Lame O, Bellet D, Di Michiel M. Bulk observation of metal powder sintering by X-ray synchrotron microtomography. Acta Mater. 2004;52(4):977-84.

Li HG, Li HM, Gao BB. Study on pore characteristics and microstructure of sandstones with different grain sizes. J Appl Geophys. 2017a;136:364-71. https://doi.org/10.1016/j.jappg eo.2016.11.015.

Li P, Zheng M, Bi H, et al. Pore throat structure and fractal characteristics of tight oil sandstone: a case study in the Ordos Basin, China. J Pet Sci Eng. 2017b;149:665-74. https://doi. org/10.1016/j.petrol.2016.11.015.

Liu B, Yao SP, Hu WX, et al. Applying octamethylcyclotetrasiloxane as a probe liquid for characterizing the pore size distribution of oil-bearing tight sandstones by nuclear magnetic resonance cryoporometry. Mar Pet Geol. 2017;88:814-25. https://doi. org/10.1016/j.marpetgeo.2017.09.022.

Patrick W, Ulrike H, Bastian K, et al. Critical evaluation of an upper carboniferous tight gas sandstone reservoir analog: diagenesis and petrophysical aspects. Mar Pet Geol. 2017;86:689-710. https://doi.org/10.1016/j.marpetgeo.2017.05.034.

Schmitt M, Fernandes CP, Wolf FG, et al. Characterization of Brazilian tight gas sandstones relating permeability and angstrom-to micron-scale pore structures. J Nat Gas Sci Eng. 2015;27:785807. https://doi.org/10.1016/j.jngse.2015.09.027.

Shanley KW, Cluff RM. The evolution of pore-scale fluid saturation in low-permeability sandstone reservoirs. AAPG Bull. 2015;99(10):1957-90. https://doi.org/10.1306/03041411168.

Shao XH, Pang XQ, Jiang FJ, et al. Reservoir characterization of tight sandstones using nuclear magnetic resonance and incremental pressure mercury injection experiments: implication for tight sand gas reservoir quality. Energy Fuels. 2017;31:10420-31. https:// doi.org/10.1021/acs.energyfuels.7b01184.

Song Y, Jiang L, Ma XZ. Formation and distribution characteristics of unconventional oil and gas reservoirs. J Palaeogeogr. 2013;15(5):602-13 (in Chinese).

Sonnenberg SA, Pramudito A. Petroleum geology of the giant elm coulee field, williston basin. AAPG Bull. 2009;93(9):1127-53.

Sun Y, Deng M, Ma SZ, et al. Distribution and controlling factors of tight sandstone oil in Fuyu oil layers of Da'an area, Songliao basin, NE China. Pet Explor Dev. 2015;42(5):589-97. https://doi. org/10.1016/S1876-3804(15)30059-8.

Sun LD, Zou CN, Jia AL, et al. Development characteristics and orientation of tight oil and gas in China. Pet Explor Dev. 2019;46(6):1015-26. https://doi.org/10.11698/PED.2019.06.01.

Tang MM, Zhao HY, Ma HF, et al. Study on $\mathrm{CO}_{2}$ huff- $n$-puff of horizontal wells in continental tight oil reservoirs. Fuel. 2017;188:140-54. https://doi.org/10.1016/j.fuel.2016.10.027.

Tian JX, Zeng X, Yi SW, et al. The prediction method of the tight oil reservoirs "sweet spot" in saline lacustrine basin: a case study of the upper Ganchaigou formation in the Zhahaquan district of Qaidam basin. Earth Sci Front. 2016;23(5):193-201. https://doi. org/10.13745/j.esf.2016.05.021. 
Tian L, Yang DY, Zheng SX, et al. Parametric optimization of vector well patterns for hydraulically fractured horizontal wells in tight sandstone reservoirs. J Pet Sci Eng. 2018;162:469-79. https://doi. org/10.1016/j.petrol.2017.12.054.

Wall CG. Permeability-pore size distribution correlations. J Inst Pet. 1965;51:498.

Wang CY, Wang ZC, Wang JL. Reconstruction of Paleo river systems and distribution of sedimentary facies of Shanxi and lower Shihezi formations in southern Ordos Basin. J China Univ Min Technol. 2008;18(2):241-4. https://doi.org/10.1016/S1006-1266(08)60051 $-6$.

Wang WM, Lu SF, Chen X, et al. A new method for grading and assessing the potential of tight sand gas resources: a case study of the Lower Jurassic Shuixigou Group in the Turpan-Hami Basin. Pet Explor Dev. 2015;42(1):60-7. https://doi.org/10.1016/S1876 -3804(15)60007-6.

Wang Q, Ma DX, Yu F, et al. The diagenetic evolution and quantitative research of porosity in different grain size sandstones of the lower Shihezi formation in Linxing area, Ordos Basin. Acta Sedimentol Sin. 2017a;35(1):163-71. https://doi.org/10.14027/j.cnki. cjxb.2017.01.016.

Wang H, Ran QQ, Liao XW. Pressure transient responses study on the hydraulic volume fracturing vertical well in stresssensitive tight hydrocarbon reservoirs. Int J Hydrog Energy. 2017b;42(29):18343-9. https://doi.org/10.1016/j.ijhyd ene.2017.04.143.

Wang M, Tang HM, Zhao F, et al. Controlling factor analysis and prediction of the quality of tight sandstone reservoirs: a case study of the He8 Member in the eastern Sulige gas field, Ordos Basin, China. J Nat Gas Sci Eng. 2017c;46:680-98. https://doi. org/10.1016/j.jngse.2017.08.033.

Xi KL, Cao YC, Jens J, et al. Diagenesis and reservoir quality of the lower cretaceous Quantou formation tight sandstones in the southern Songliao basin, China. Sediment Geol. 2015;330:90-107. https://doi.org/10.1016/j.sedgeo.2015.10.007.

Xi KL, Cao YC, Haile BG, et al. How does the pore-throat size control the reservoir quality and oiliness of tight sandstones? The case of the lower cretaceous Quantou formation in the southern Songliao basin, China. Mar Pet Geol. 2016;76:1-15. https://doi. org/10.1016/j.marpetgeo.2016.05.001.

Xiao DS, Lu SF, Lu ZY, et al. Combining nuclear magnetic resonance and rate-controlled porosimetry to probe the pore-throat structure of tight sandstones. Pet Explor Dev. 2011;43(6):961-70. https:// doi.org/10.11698/PED.2016.06.13.

Xiao DS, Lu SF, Yang JX, et al. Classifying multiscale pores and investigating their relationship with porosity and permeability in tight sandstone gas reservoirs. Energy Fuel. 2017;31(9):9188-200. https://doi.org/10.1021/acs.energyfuels.7b01487.

Xiao DS, Jiang S, Thul D, et al. Impacts of clay on pore structure, storage and percolation of tight sandstones from the Songliao Basin, China: implications for genetic classification of tight sandstone reservoirs. Fuel. 2018;211:390-404. https://doi.org/10.1016/j. fuel.2017.09.084.

Xie YG, Qin Y, Ye JP, et al. Accumulation conditions of tight gas in the Upper Paleozoic of Linxing Block. J China Coal Soc. 2016;41(1):181-91. https://doi.org/10.13225/j.cnki. jccs.2015.9010 (in Chinese with an English Abstract).

Yu XH, Li SL, Yang ZH. Discussion on deposition-diagenesis genetic mechanism and hot issues of tight sandstone gas reservoir. Lithol Reserv. 2015;27(1):1-13 (in Chinese with an English Abstract).

$\mathrm{Yu}$ Y, Lin L, Zhai C, et al. Impacts of lithologic characteristics and diagenesis on reservoir quality of the 4 th member of the Upper Triassic Xujiahe Formation tight gas sandstones in the western Sichuan Basin, southwest China. Mar Pet Geol. 2019;107:1-19. https://doi.org/10.1016/j.marpetgeo.2019.04.040.

Yue DL, Wu SH, Xu ZY, et al. Reservoir quality, natural fractures, and gas productivity of upper triassic Xujiahe tight gas sandstones in western Sichuan basin, China. Mar Pet Geol. 2018;89:370-86. https://doi.org/10.1016/j.marpetgeo.2017.10.007.

Zhang YC, Zeng JH, Qiao JC. Experimental study on natural gas migration and accumulation mechanism in sweet spots of tight sandstones. J Nat Gas Sci Eng. 2016;36:669-78.

Zhao JZ, Pu X, Li YM, et al. A semi-analytical mathematical model for predicting well performance of a multistage hydraulically fractured horizontal well in naturally fractured tight sandstone gas reservoir. J Nat Gas Sci Eng. 2016;32:273-91. https://doi. org/10.1016/j.jngse.2016.04.011.

Zhao XZ, Pu XG, Han WZ, et al. A new method for lithology identification of fine grained deposits and reservoir sweet spot analysis: a case study of Kong 2 member in Cangdong sag, Bohai Bay Basin, China. Pet Explor Dev. 2017;44(4):524-34. https://doi. org/10.1016/S1876-3804(17)30061-7.

Zhou Y, Ji YL, Xu LM, et al. Controls on reservoir heterogeneity of tight sand oil reservoirs in upper triassic Yanchang formation in Longdong area, southwest Ordos Basin, China: implications for reservoir quality prediction and oil accumulation. Mar Pet Geol. 2016;78:110-35. https://doi.org/10.1016/j.marpe tgeo.2016.09.006.

Zhu HH, Zhong DK, Zhang TS, et al. Diagenetic controls on the reservoir quality of fine-grained "tight" sandstones: a case study based on NMR analysis. Energy Fuels. 2018;32:1612-23. https://doi. org/10.1021/acs.energyfuels.7b03734.

Zou CN, Zhang GS, Yang Z, et al. Geological concepts, characteristics, resource potential and key techniques of unconventional hydrocarbon: on unconventional petroleum geology. Pet Explor Dev. 2013;40(4):385-99. https://doi.org/10.1016/S1876 -3804(13)60053-1.

Zou CN, Yang Z, Zhang GS, et al. Conventional and unconventional petroleum "orderly accumulation": concept and practical significance. Pet Explor Dev. 2014;41(1):385-99. https://doi. org/10.1016/S1876-3804(14)60002-1. 